\title{
The impact of role modeling on the professional identity of pre-service teachers
}

\author{
Lizette Drusila Flores Delgado*, Irlanda Olave Moreno, and Ana Cecilia Villarreal Ballesteros \\ Facultad de Filosofía y Letras, Universidad Autónoma de Chihuahua, Rúa de las Humanidades, s/n, \\ Campus Universitario I, Chihuahua, Chih., Mexico
}

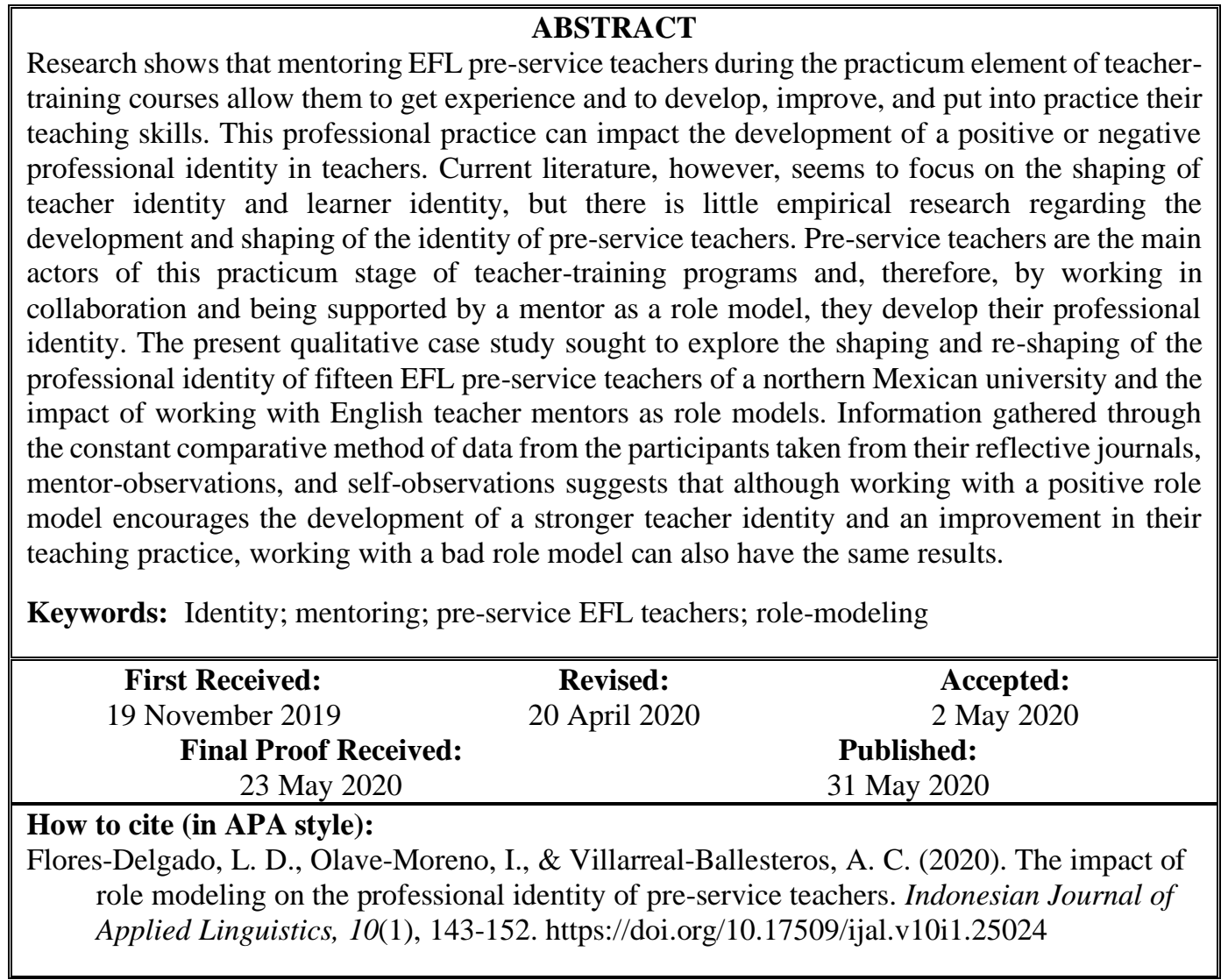

\section{INTRODUCTION}

Research on teacher training and education has shown that the first five years of teaching are crucial for pre-service teachers since the risk of leaving the profession (teacher attrition) during this time is higher (Delaney, 2012; Flores \& Day, 2006; Johnson, 2003). This is due to several factors such as the clash between the commonly idealistic expectations held by pre-service teachers and the reality they face including lack of support from other teachers and the school administration, and lack of confidence in their teaching skills, among others. Several studies claim that when teachers work with colleagues in a supportive environment, they acquire a sense of belonging that encourages them to improve their performance and is likely to reduce the risk of abandoning the profession (Burke et al., 2015; Varghese et al., 2009).

Although teacher-training programs in universities provide students with current theory on language acquisition and teaching methodology and strategies, pre-service teachers, that is, students who are registered to a university program learning to be teachers, need to experience real contexts during the practicum phase. This will allow them to learn and develop their teaching skills while they experience first-hand classroom management, explanation of topics, and experiment by applying activities and strategies according to different types of students, etc. The practicum course is aimed at helping them to become confident teachers before finishing university and entering the profession (Ambrosetti \&

\footnotetext{
* Corresponding Author

Email: ldflores@uach.mx
} 
Dekkers, 2010). Thus, teacher education programs have added a practicum stage to their curricula as it allows pre-service teachers to put into practice their skills in real-life contexts while being observed, guided, and supported by more experienced language teachers who act as their mentors and who serve as their role models.

Pre-service teachers often have a predetermined image of what being a teacher is like, and they expect their role models to reflect this image. For the purposes of this study, a role-model refers to an experienced English teacher who mentors and supports pre-service teachers (mentees) professionally, academically, emotionally, and personally. This mentorship is done to help preservice teachers to develop their teaching skills in collaboration with a more experienced teacher (Ehrich, 2013; Galbraith, 2003; McCall, 2011).

The way pre-service teachers perceive their mentors affects the development of their skills and the shaping of their professional identity. When starting their practicum, pre-service teachers tend to have idealistic expectations not only of what teaching is like but also of their mentors as role models. Timoštšuk and Ugaste (2010) claim that pre-service teachers usually expect their mentors to be highly prepared professional teachers with 'perfect' class control, high English proficiency and who are both personally and academically supportive. When these characteristics are not met, mentees feel disappointed and their perceptions of what teaching and being a teacher mean can change, affecting thus their professional identity.

According to Walkington (2005), professional identity refers to the beliefs a person has about teaching and being a teacher. Research suggests that although teachers usually have an idea of the kind of professional they want to be even before they enter the profession, their professional identity is likely to be re-shaped when they start teaching, get experience, and interact with students, teachers, parents, and school administrators (Delaney, 2012; Izadinia, 2015; Johnson, 2003; Maynard \& Furlong, 1995; Timoštšuk \& Ugaste, 2010). This re-shaping of identity also occurs during practicum as it is in this stage that pre-service teachers challenge their beliefs on teaching by adapting to the needs, methodologies, and beliefs of their mentors and of the institutions where they have to teach. It is therefore crucial that during this stage pre-service teachers receive support and scaffolding from their mentors and are exposed to positive role models so that they can imitate what they consider to be good teaching practice, develop a positive and strong teacher identity, and are less likely to suffer from the teacher attrition described above.

The opinions that pre-service teachers form of their mentors as role models during practicum could have an impact on the ways in which they perceive teaching. This study, which is a follow-up based on the research of a Doctoral thesis (Flores-Delgado, 2019), therefore, seeks to explore how the professional identity of pre-service teachers may be re-shaped by working with mentors that they consider to be good or bad role models as English as a Foreign Language (EFL) teachers in Mexico. It also attempts to contribute to the literature of the development of professional identity in pre-service EFL teachers, as current research focuses mainly on novice teachers.

\section{METHOD}

This qualitative case study seeks to explore how the perceptions that pre-service teachers hold of their mentors as role models may affect the shaping of their teacher professional identity during the practicum stage of their B.A. program in a university in northern Mexico. It attempted to answer the research question: In what ways do the opinions that pre-service teachers form of their mentors contribute to the shaping or re-shaping of their professional identity?

The study was carried out between January 2018 and June 2019 with three cohorts of fifteen preservice teachers registered in a B.A. in English Language in a public university in the north of Mexico. Participants were taking the course TESOL practicum in the last term of their 9 semesters B.A. program and were assigned to five different schools from elementary to high school levels.

A qualitative approach was chosen because, as Merriam (2009) claims, it focuses on meaning in context by exploring how people perceive and interpret their own reality. This case study attempts, therefore, to show how the development of the professional identity of these three cohorts of preservice EFL teachers may be affected by the perceptions that they hold of their mentors as English teachers and as role models during their practicum experience.

\section{Participants of the study}

The participants of this study were chosen in line with the characteristics of Merriam (2009) of sample selection being non-random, purposeful, and small in qualitative case studies. As previously mentioned, the participants were fifteen ninth semester pre-service teachers from three cohorts of a B.A. in English Language. Data from four participants of the first cohort (C1) were collected between January and June 2018, from five participants of the second cohort (C2) between August and December 2018, and from six participants of the third cohort (C3) between January and June 2019. Purposive sampling (Bailey, 2007) was used as participants were chosen through the judgment of the researchers according to the purposes of this study; that is, they had to be registered in the TESOL: Practicum course, and had to be working with an English teacher mentor in a different 
institution. There were twelve female and three male participants.

As previously mentioned, participants were assigned to five different schools. Schools were chosen by convenience due to proximity to the university or because graduates of the same B.A. program work there so they were willing to receive pre-service teachers (see Appendix Table 1: Practicum schools).

At the beginning of the semester, schools were contacted by the supervisors of the TESOL Practicum course, who are university professors in charge of this class. Supervisors contacted the principals of the schools and gave them written information about the activities and tasks that pre-service teachers were supposed to do during the semester. Principals, then, chose the English teachers who would be mentoring the participants of the study, and mentors were also given written information regarding the way they would work with the pre-service teachers, what was expected from them as mentors, and what the preservice teachers were supposed to do. Pre-service teachers, mentors, principals, and supervisors had the phone numbers and e-mails of each other in case questions regarding practicum arose in the future. After mentors were chosen by the school principals, each school set the schedule that the pre-service teachers were going to attend the institutions, and each mentor decided the specific way in which they would work with the participants of this study to achieve the goals set by the TESOL: Practicum course. Pre-service teachers were randomly assigned to the schools by the supervisors. The following mentoring situations occurred:

- School 1: Participants were asked to teach a group of intermediate - upper-intermediate (B1 - B2 levels according to the Common European Framework of Reference) English learners on their own. That is, these English learners did not have a regular English teacher as this course was an extracurricular class to improve their skills to take an English certification. Therefore, preservice teachers became their English teachers from day one. Participants, thus, began teaching since they started the semester and were assigned to an English teacher from a different class as their mentors so that mentees were able to complete their university tasks. They observed the mentors and learned from them through the analysis required in their university observation tasks but did not work in collaboration with them for the planning of their own teaching. The coordinator of the English classes and the university supervisors were in charge of observing and giving feedback to these preservice teachers.
- Schools 2, 3, 4 and 5: Participants were assigned to work with a group of beginner elementary (A1 - A2 levels according to the CEFR) English learners and with their regular English teachers. The English teachers became the pre-service teachers' role models and mentors. Mentors decided in which classes the participants would be working as their assistants, which classes they could teach on their own, and which they would only observe. Mentors and university supervisors were in charge of observing and giving feedback to preservice teachers.

Regarding the professional identity of the participants of the study, the fifteen of them claimed to be interested in teaching to some degree and had a positive image of being a teacher. However, four participants expressed that although they liked teaching, they did not feel confident in their teaching skills, and one said that although he liked teaching, he would prefer to be a translator. The B.A. program where participants are enrolled, prepares students to be both teachers and translators, so it is common that some of them are more interested in one of these two areas than in the other.

\section{Instruments}

The reflection of pre-service teachers' practice was the main element of this study, as the focus was to analyze the perceptions that the participants held of their mentors. Therefore, the instruments used for data collection were reflective journals, mentor observation by participants, self-observations through video by the pre-service teachers, and participant video and face-to-face observations by the university supervisors.

Participants were asked to write a weekly reflective diary entry where they described what happened in class, how they felt, what they learned, and how they could improve their teaching or what suggestions they would give to their mentors to improve theirs. Reflective journals allow teachers to analyze and interpret their actions in the classroom to later re-shape them to improve their practice (Antonek et al., 2007; Scanlon et al., 2002).

In addition, to encourage participants to reflect on the teaching practice of their mentors and on their own, pre-service teachers were asked to complete fourteen observation tasks. There were seven mentorobservation tasks related to different areas of teaching (conditions for learning, giving instructions, teacher action zone, blackboard use, use of the mother tongue, classroom management and discipline, and promoting language use and communication), and seven self-observation tasks to reflect on their own practice (general impressions and use of voice, giving instructions, teacher action zone, blackboard use, use of the mother tongue, classroom 
management and discipline, and promoting language use and communication). Participants were asked to record themselves while teaching to complete the self-observation tasks. These tasks allowed mentees to focus on specific areas of teaching to later analyze and reflect on what they or their mentors did to plan strategies to improve their future teaching.

Moreover, university supervisors observed the participants face to face at least twice during the semester and gave them weekly feedback based on the videos of their classes. Supervisors made a list of the strengths and areas of opportunity of the preservice teachers and later discussed them together to plan how to improve their practice. Participants also discussed their practice during weekly classroom sessions where the other pre-service teachers watched their videos and gave advice and suggestions, constructing, thus, peer-mentoring relationships. According to Ehrich (2013), peer mentoring involves people who are at the same level or status and who decide to work together to help each other. In the case of this study, peer-mentoring was beneficial for pre-service teachers as it allowed them to reflect not only on their own teaching practice and on that of their mentors but also on the teaching practice of their classmates. Therefore, participants tried to solve classroom problems in collaboration by supporting each other and by learning through the experiences of others.

\section{Procedures and data analysis}

To analyze data, diary entries and reflective worksheet tasks were digitized and uploaded to the software NVivo. This software by QSR international is used to analyze text, audio, video, etc., such as interviews, focus groups, surveys, among others; hence, it is commonly used in qualitative and mixed methods research. To protect the identity of the participants, data were anonymized by giving them a code using the cohort number and a letter taken from their names. This way participants were identified as C1A, C1E, C2C, C2G, C3L, C3N, etc.

Instruments were transcribed verbatim in NVivo and data were analyzed through the constant comparative method (CCM) adapted by Lincoln and Guba (1985), following an axial coding technique (Glaser \& Strauss, 1967). The process of coding was done in two cycles.

During the first cycle, data were analyzed and categorized participant by participant according to emerging themes of role modeling and identity. Information was coded in NVivo according to general categories based on the literature first, and then on secondary categories that emerged from the data. The general categories were positive identity, negative identity, opinions about mentor, positive perceptions of teaching, and negative perceptions of teaching.

Then, during a second cycle, as axial coding relates categories to subcategories that were previously created; they were analyzed, compared, and contrasted by cohort. That is, after each participant's information was categorized, it was compared and contrasted with the information of the other participants of the same cohort, and later of the other two cohorts. The newly collected information was compared and contrasted with previously collected data to find similarities and allow transferability that could later permit other researchers to repeat the study in similar contexts (Shenton, 2004).

\section{FINDINGS}

This section reports on findings that resulted from the analysis of the previously described categories. It is divided into two sections. The first one describes the expectations participants had of mentoring and of their mentors, and how they were challenged once that they started their practicum. The second section describes how participants felt that role-modeling during their practicum stage affected their perceptions of teaching and of being teachers.

\section{Perceptions of pre-service teachers about their mentors}

Findings suggest that pre-service teachers held high expectations of their mentors during their practicum stage and that they often felt disappointed when their idealistic assumptions were not met. Participants claimed that they anticipated their mentors to have full control of the class in terms of discipline; they expected them to have at least a bachelor's degree or a certification in language teaching, high proficiency in English, and that they taught dynamic classes mainly in English without much use of the students' first language.

Before meeting their mentors, participants were asked what they expected from them, how they thought they would be like. Participant C1R, for instance, claimed:

"Well, I think that as my mentor works in a secondary school she should be really good at managing the class, probably have a degree or certification in teaching; working with teens is hard, so she should know how to do it."

Likewise, C2G said: "I think my mentor will be a professional teacher, that is, someone maybe not with a degree in English, but at least in something else and a certification in teaching English."

These quotes portray the general hope of participants had of their mentors being professional teachers who are well-trained to teach a language course. Besides, other participants focused on the delivery of the class rather than on the educational background of the mentor.

Participant C2V, for instance, claimed that she hoped that her mentor "gives a fun class and has good English. When you teach kids you need to be very 
dynamic, to do a lot of different activities so that the students don't get bored."

Similarly, C3L claimed that he hoped that his mentor

"uses games and knows how to keep students quiet. I think the games are a good way of keeping them quiet and entertained, and then they can pay more attention so if the teacher speaks to them in English they will be able to get what she is saying."

These two statements show that participants also expected their mentors to be dynamic and to teach the class in the target language.

However, once that they met their mentors, some participants felt disappointed as the classes were not as they had expected. As mentioned in the previous section, pre-service teachers were asked to write a weekly journal and there were weekly meetings where all of them shared their experiences, feelings, and frustrations. There, mentees discussed in which situations they felt disappointed and even angry about what was going on in the classes they were observing and teaching.

$\mathrm{C} 2 \mathrm{~J}$, for instance, claimed "I don't like this class, my mentor speaks only in Spanish and the kids don't pay attention to her. Also, she is yelling all the time; it is very stressful!"

$\mathrm{C} 1 \mathrm{M}$ also showed her disappointment when she said that her mentor

"is always yelling at the kids, she is very impatient. Also, although she speaks in English she gets upset when students ask her something because they don't understand her, and she doesn't make them participate, she wants them to be quiet all the time!"

Similarly, C2M also expressed that she was not happy with her mentor's behavior, but she seemed to realize that probably her expectations were too high at first:

"I don't know how to feel. I don't like it that the teacher speaks in Spanish a lot or that she is yelling all the time, but there are some kids that are very difficult and don't pay attention to the class. I don't know how she is not crazy yet!"

These statements seem to show that the prepracticum image that participants had of their mentors began to be challenged once that they observed them in a real teaching context, as they realized that mentors do not always have full control of the class, and that they do not teach in ways they believe are "ideal". Pre-service teachers began realizing that teaching is not as easy and as idealistic as they expected, especially in groups with more than 20 students, and that mentors are humans who get frustrated and lose their temper sometimes.

Another aspect of mentors that was criticized by participants was their use of English. Participants $\mathrm{C} 1 \mathrm{~A}, \mathrm{C} 1 \mathrm{E}, \mathrm{C} 2 \mathrm{C}$ and $\mathrm{C} 3 \mathrm{~S}$ made comments regarding their mentors not knowing or forgetting basic English vocabulary when students asked them for the meaning of words. $\mathrm{C} 2 \mathrm{C}$, for example, said: " $M y$ mentor is very impatient and she ignores students when she does not know how to answer their questions. She just pretends she didn't listen." Similarly, mentee C1E claimed that her mentor misspelled new words that students were learning, and $\mathrm{C} 3 \mathrm{~S}$ complained about her mentor making basic grammar mistakes. Mentees believed that these situations made mentors lose credibility as teachers. C1E said, "I know we are not dictionaries, but her mistakes were very basic for a teacher. Students noticed it and then they paid even less attention to her."

Nevertheless, not all the comments about the mentors were negative. Participants also described the ways in which their mentors supported them and the aspects of their teaching that they liked.

$\mathrm{C} 2 \mathrm{G}$, for instance, said that her mentor was supportive from day one: "He is awesome. The moment I arrived, he introduced me as a teacher and told students that they would have two teachers instead of one so that they learn better."

Similarly, both C1R and C2V, who had the same mentor but during different periods as they belonged to different cohorts, claimed that their mentor introduced them as teachers and told students that they would have the same authority in the classroom as her. "It felt really good because it made me feel like a real teacher!" said $\mathrm{C} 2 \mathrm{~V}$.

These statements show that being recognized as teachers or being treated as equals by their mentors had a positive impact on the teacher identity of participants.

Other participants, C1R, C2J, C3T, C3N, C3P, also mentioned that they enjoyed some of the activities and strategies that their mentors used when teaching.

C2J, for instance, claimed that although she does not like how her mentor kept discipline, she also "prepares very fun activities using superheroes or characters that students like, so kids pay attention and they learn more than when she is yelling."

$\mathrm{C} 3 \mathrm{~V}$ likewise mentioned that her mentor "teaches fun classes. He is always doing activities different from the book, so students are active and pay attention. I noticed that they get less distracted like this than when they are only answering book exercises."

These statements suggest that participants are not only noticing the types of activities that their mentors use in class, but that they are also criticizing and reflecting on them as they are noticing the effects that those strategies have on discipline and on the learning of the students. All these elements had an impact on the future teaching of pre-service teachers. Participants mentioned that they would incorporate these activities into their teaching when it was their time to teach, and also, at the time of giving suggestions to their classmates during the weekly sessions, they used their mentors' strategies as advice. 
During a weekly discussion session, C1R, for instance, told C1E: "I really liked an activity my mentor used with a traffic light with the names of the students, I think it can help you with discipline in your class." Similarly, C3P gave C3L some ideas to improve his flashcards to get the attention of the students, like her mentor did:

"Use Superheroes to teach the verbs! My mentor did that and then students paid attention as soon as they saw them. Just be careful because then they will start talking too much about their favorite ones, so use that to start a discussion."

Mentoring as role modeling, therefore, seems to impact the way pre-service teachers see teaching and thus, can affect the shaping of their professional identity.

\section{Perceived impact of role modeling in teacher identity}

This second section presents findings that deal with the ways in which participants perceived that mentoring as role modeling impacted in the shaping of their identity. As mentioned in the introduction of this paper, the fifteen participants claimed to have a positive image of teaching. They described it as hard but rewarding, enjoyable, fun, interesting, creative, life-changing, and that it makes them grow as persons because teachers have to be constantly preparing themselves, "you're always learning" (C1E). So, if participants already held a positive teacher identity, was it possible that their practicum experience changed their views? Here the analysis focuses on the impact that having what students perceived as a good or a bad role model had on them, as well as on the impact that teaching a real class could have had.

Findings suggest that participants who had what they considered a good and encouraging mentor and role model became more confident when teaching.

Participant C1A said that

"when I was observed, my mentor and my supervisor told me that I did a good job. This was my first time teaching so many teenagers who already spoke English so I didn't know if I could do a good job planning a lesson for this level. When they congratulated me, it felt so good and I felt more motivated to teach."

Likewise, participant $\mathrm{C} 2 \mathrm{~V}$ claimed that the support of her mentor made her more confident: "She was always helping me and she gave me a lot of authority in the class, also after my classes she gave me tips on how to deal with the students because I struggled a lot with that." The help and scaffolding by her mentor allowed this participant to strengthen her identity as a teacher as she also said that her mentor "made me realize that I can teach, I felt like a real teacher and I am very grateful."

Participant $\mathrm{C} 3 \mathrm{~V}$ also highlighted the role of her mentor in her practicum:

"He is very supportive. He gives me ideas and he makes me feel like a real teacher because he lets me make decisions in the classroom. He has also said that he liked my activities and he asked me if he can use them too."

Findings suggest, therefore that when preservice teachers are supported and they feel they are being treated as equals by their mentors, they feel motivated and their confidence in teaching increases. Participants who claimed that their mentors guided them and made them feel like "real teachers" showed an improvement in their teaching as they began imitating the behavior they liked of their mentors, and trying to change the behavior they did not like, all this according to their own perception based on their journals, self-observations, and on the observations made by their mentors and supervisors.

Participant C1R said:

I feel I have improved my teaching a lot. My mentor told me I had to be stricter with my students and she said that I had to raise my voice. My supervisor also told me that I needed to monitor the students because I just stayed in front of the classroom so I began doing what my mentor does and started walking through the rows around the classroom... At the end of the practicum both told me that I had improved the ways I managed the class.

Similarly, participant C2L said:

At the beginning of the practicum I was very nervous because there were so many students and I had never taught before, but with the help of my mentor I learned how to behave like a teacher. I learned I had to set my authority and I also learned what activities worked better. My supervisor also gave me tips on activities, for example to use popular characters they liked, and it worked!

Having a positive teacher identity and having a good role model allows pre-service teachers to improve their practice. Nevertheless, not all the participants considered that their mentors were good English teachers. Findings also suggest that the positive teacher identity of pre-service teachers was not negatively re-shaped by working with what participants considered a bad role model. Data showed that participants used their learning from bad role models as standards of what not to do in their classes as they did not want to be perceived by students as bad teachers.

For instance, participant $\mathrm{C} 1 \mathrm{M}$ expressed her concern about her teaching skills: "I would like to become a teacher, but I don't think I am good at it. I'm too shy and I feel I won't be able to control the students."

When she worked with her mentor, she claimed that she did not like her classes because "my mentor mostly uses book activities and she does not control the class. She is a new teacher and I think she gets too desperate with the students."

This observation allowed her to work in collaboration with the teacher and they both supported each other: 
When I planned my classes I remembered the things I didn't like about my mentor's class, so with the help of my supervisor and my classmates I got ideas to plan activities that could keep my students busy and to monitor them so that they behaved well ... my mentor liked my classes and she sometimes asked me for tips so we sometimes helped each other, too. I don't know how to feel about this because I wanted to learn from her, not that she asked me how to teach (C1M).

This shows that although the pre-service teacher thought that her mentor was a bad role model, she was supportive of the mentee and willing to learn from her, having, thus, characteristics of a good mentor.

Participant C2J was in a similar situation. She claimed that:

I had to think a lot when I planned my classes because I didn't want to teach like my mentor. It stresses me a lot that she was always yelling, and I thought students were not learning... When I planned my lessons, I tried to include other activities that were fun and that kept the students busy because I didn't want my students to think that I was like my mentor.

Participant $\mathrm{C} 2 \mathrm{~J}$ had stated at the beginning of the semester that although she liked teaching, she was not sure if she had the skills required to teach. This self-perception allowed her to prepare herself better because as she mentioned she "had to prove to myself that I could teach or else, I had to prove that I couldn't so I chose a different professional path when I graduated."

By the end of the semester, this participant claimed that feedback from her supervisor helped her improve her teaching:

"I always listened to and read many times the comments from my supervisor and I always had in mind my mentor's classes when I planned mine. I think I improved a lot and I would like to teach in the future, but preferably adults, I still get too stressed with the kids".

This shows that this participant improved not only her teaching but also her reflective and metacognitive skills, as she was constantly thinking about the feedback she had received during her planning process.

Similarly, participant C3S was unsure of her teaching skills. She had taught before but not highschool students. This participant carried out her practicum in School 1, that is, she was not assigned a mentor to observe her:

I had taught classes before, but private classes. I admit I'm afraid of teaching on my own from the beginning because I had never taught so many students!"... "Feedback from my supervisor helped me feel confident and now [end of practicum] I don't feel afraid anymore. I love this and I definitely want to become a teacher.
These comments show that the perceptions that pre-service teachers hold on teaching may be stronger than the influence of good or bad modeling from their mentors. Moreover, they seem to show that a positive image of teaching may aid in the development of the teaching skills of the participants.

\section{DISCUSSION AND CONCLUSION}

Role modeling from mentors during practicum seems to play an important role in the shaping of the teacher identity of pre-service teachers. This section, thus, provides answers to the research question presented in the introduction based on the results obtained and on the literature consulted.

The practicum stage of a teacher training program can contribute to the reinforcement of a strong teacher identity in pre-service teachers. The participants of this study already held a positive view on teaching and, although at the beginning of their practicum they had idealistic views and were hoping for a "perfect" classroom and a "perfect" English teacher as a mentor and role model, the reality shock they faced encouraged them to prepare their classes better.

Flores and Day (2006) claim that this reality shock is common in the transition from pre-service teachers to novice teachers because they are forced to take full responsibility for a classroom. Therefore, in the early stages of teaching, that is, during the practicum stage, controlled support or scaffolding is important so that pre-service teachers develop confidence in their teaching skills and they are able to overcome this reality shock with ease. The results of this study showed that collaboration and scaffolding allowed pre-service teachers to gain confidence in their teaching, to plan better lessons, and to reduce stress. In this study, pre-service teachers did not take full responsibility for a classroom as they were supported and scaffolded by their mentors, supervisors, and peers. Whenever they had problems, either related to teaching or to classroom management, they turned to people for help and advice, and hence, they felt more relaxed as they knew they had someone to rely on. This goes in line with Reis (2015), who argues that the negative feelings of anxiety and lack of confidence that novice teachers experience can be reduced by the assistance and support of others.

Role modeling from mentors, therefore, is important in the shaping of the identity of pre-service teachers, regardless if it is from what pre-service teachers consider to be a good or a bad teacher. Good role models guide and support pre-service teachers by allowing them to experiment with different techniques and strategies in their classes, providing participants not only with a good example of teaching but also with a positive mentoring experience. When pre-service teachers feel supported by their mentors, they are more likely to ask questions and to engage in 
discussion about their practice. This promotes reflection on what pre-service teachers can do to improve their future classes and to help and get help from their mentors. This resulted in participants and mentors developing a collaborative relationship where they were able to support and give feedback to each other.

Participants who considered they were working with a mentor who was a good teacher and a good role model received constant feedback. Pre-service teachers tended to replicate the behavior that they admired from their mentors such as delivering the class mostly in English and being patient and supportive with the students. They also replicated the use of activities and strategies, class dynamics and control, as well as feedback techniques that they considered effective for the learning of the students. These participants claimed that their mentors made them feel more confident about their teaching skills, and at the end of their practicum, they felt that they had improved not only their teaching skills but also their self-esteem as teachers. This goes in line with Freiman-Nemser (1996) who claims that this type of supportive environment is an improvement over the abrupt entrance in the teaching profession that causes teacher attrition when teachers feel unmotivated, discouraged, unsupported, and alone. Therefore, by being exposed to a real teaching environment with the help of a role model during university, pre-service teachers enter the profession once they finish school feeling more confident and capable to teach, reducing thus the possibility of leaving the profession.

On the other hand, participants who considered they were working with bad teachers also improved their teaching skills. This happened because they had theoretical preparation from their university courses, had supportive supervisors and peers who encouraged them, and because they perceived their mentors as models of what they did not want to do, of the kind of teacher they did not want to be. This may be because most participants wanted to be teachers, so they had a positive image of this profession and they felt that their mentors went against their beliefs and principles of what good teaching was like. Therefore, they wanted to be perceived as professional, prepared teachers because they did not want their students to think that they were "bad" teachers, which is what they sometimes thought of their mentors. Nevertheless, it is worth noticing that these "bad" teachers were also supportive of their mentees, as they not only gave them advice and tried to help them, but also sometimes asked participants to give them feedback and to help them plan their classes; that is, a relationship of collaboration emerged in which both mentor and mentee supported each other. This collaboration made pre-service teachers feel confident about their skills because although their mentors were, in their opinion, "bad" teachers, they were more experienced teachers than them and they were asking them for support to improve their teaching. Based on the results of this study, effective mentors are teachers who are supportive, willing to collaborate, and treat pre-service teachers as equals, regardless if mentees consider them to be good or bad English teachers. Being a good or a bad teacher and a good or bad mentor seem to be, thus, different things.

There seems to be an element of pride here that can be associated with what Gee (2000) calls the D and the I identities. D-identity refers to the characteristics that people recognize in themselves as teachers and it is strengthened or weakened based on the person's I-identity, which refers to the characteristics that others give to a teacher (Gee, 2000). That is, the professional identity of teachers is strengthened depending on how similar their D and I identities are. In the case of this study, pre-service teachers held a positive image of being a teacher (Didentity) and they wanted their students and mentors to recognize in them positive characteristics of teachers too (I-identity). Because of this, participants who worked with a bad role model got engaged in reflective practice to analyze the behavior of their mentors and of themselves to plan how to teach their own lessons. In addition, they turned to their supervisors and classmates for ideas and suggestions to improve their practice. Mentors' attitudes and behaviors have a great impact on the formation of their mentees' teacher identity. One implication for education programs has to do with the planning of the practicum experience for pre-service teachers. It seems that mentees might benefit from interacting with different mentors at different times so they can assess different teaching styles and find approximations to their expectations and aspirations on quality teaching. In this way, they can assess and reassess their identity in the light of the experiences allowed by different kinds of mentors.

It seems, therefore, important that teachingtraining programs in universities implement a teaching practicum stage where pre-service teachers work with mentors that can act as role models by motivating, collaborating, and supporting mentees. This way, pre-service teachers will engage in reflective practice that will allow them to improve their teaching. This reflective practice should be encouraged during the observation of their mentors, during the planning of their lessons, and during and after teaching their classes. By having a teaching practicum stage, pre-service teachers can be exposed to real classroom contexts and can put into practice their teaching skills under the supervision and guidance of a mentor to reduce the anxiety and shock that occurs in the transition between being a student and becoming a teacher. In addition, reflective practice develops their critical thinking skills and allows them to analyze, interpret, and learn from their own teaching and the teaching of others. It is suggested that pre-service teachers start getting 
immersed in real classroom contexts as soon as their university programs can allow them to do so, so that they can have more semesters or years of practice. The present paper presented results based on preservice teachers who held a positive teacher identity, so it is also suggested that another study is carried out with participants that hold a negative identity to see how results may vary to develop a better practicum program.

\section{REFERENCES}

Ambrosetti, A. \& Dekkers, J. (2010). The interconnectedness of the roles of mentors and mentees in pre-service teacher education mentoring relationships. Australian Journal of Teacher Education, 35(6), 41-55. https://doi.org/10.14221/ajte.2010v35n6.3

Antonek, J., McCormick, D., \& Donato, R. (1997). The student teacher portfolio as autobiography: Developing a professional identity. The Modern Language Journal, 81(1), 15-27. https://doi.org/10.1111/j.15404781.1997.tb01624.x

Bailey, K. D. (2007). Methods of social research (4th ed.). The Free Press.

Burke, P. F., Aubusson, P. J., Schuck, S., Buchanan, J. $\&$ Prescott, A. (2015). How do early career teachers value different types of support? A scale-adjusted latent class choice model. Teaching and Teacher Education, 47, 241-253. https://doi.org/10.1016/j.tate.2015.01.005

Delaney, Y. (2012). Research on mentoring language teachers: Its role in language education. Foreign Language Annals, 45(s1), 184-202. https://doi.org/10.1111/j.19449720.2011.01185.x

Ehrich, L. (2013). Developing performance mentoring handbook. Department of Education, Training and Employment. Queensland University of Technology.

Flores, M. A. \& Day, C. (2006). Contexts which shape and re-shape new teachers' identities: A multiperspective study. Teaching and Teacher Education, 22, 219-232. https://doi.org/10.1016/j.tate.2005.09.002

Flores-Delgado, L.D. (2019). An exploration of the development of student-teacher autonomy and the role of professional identity and mentoring: A case study of ESOL trainees in a northern university in Mexico [doctoral dissertation]. University of Southampton. Retrieved from https://eprints.soton.ac.uk/437593/

Freiman-Nemser, S. (1996). Teacher mentoring: A critical review. ERIC Digest, ED397060. https://files.eric.ed.gov/fulltext/ED397060.pdf

Galbraith, M. (2003). Mentoring toward selfdirectedness. Adult Learning, 14(4), 9-11. https://doi.org/10.1177/104515950301400403
Gee, J. P. (2000). Identity as an analytic lens for research in education. Review of Research in Education, 25(1), 99-125. https://doi.org/10.2307/1167322

Glaser, B.G., \& Strauss, A. (1967). The discovery of grounded theory: Strategies for qualitative research. Aldine Transaction.

Izadinia, M. (2015). A closer look at the role of mentor teachers in shaping pre-service teachers' professional identity. Teaching and Teacher Education, 52, 1-10. https://doi.org/10.1016/j.tate.2015.08.003

Johnson, K. A. (2003). Every experience is a moving force: Identity and growth through mentoring. Teaching and Teacher Education, 19(8), 787800. https://doi.org/10.1016/j.tate.2003.06.003

Lincoln, Y. S., \& Guba, E. G. (1985). Naturalistic inquiry. SAGE publications.

Maynard, T. \& Furlong, J. (1995). Learning to teach and models of mentoring. In T. Kerry \& A. Mayes (Eds.) Issues in mentoring (pp.10-24). Routledge in association with The Open University,

McCall, I. D. (2011). My UniSpace: Applying ementoring to language learning. Language Learning Journal, 39(3), 313-328. https://doi.org/10.1080/09571736.2010.538950

Merriam, S. B. (2009). Qualitative research: A guide to design and implementation (3rd ed.). JosseyBass.

Reis, D. S. (2015). Making sense of emotions in the NNEST's professional identities and agency. In Y.L. Cheung, S.B. Said, \& K. Park (Eds.), Advances and current trends in language teacher identity research (pp. 31-43). Routledge.

Scanlan, J.M., Care, W.D. \& Udod, S. (2002) Unravelling the unknowns of reflection in classroom teaching. Journal of Advanced Nursing, 38(2), 136-143. https://doi.org/10.1046/j.13652648.2002.02157.x

Shenton, A. K. (2004). Strategies for ensuring trustworthiness in qualitative research projects. Education for Information, 22(2), 63-75. http://doi.org/10.3233/EFI-2004-22201

Timoštšuk, I., \& Ugaste, A. (2010). Student teachers' professional identity. Teaching and Teacher Education, 26(8), 1563-1570. https://doi.org/10.1016/j.tate.2010.06.008

Varghese, M., Morgan, B., Johnston, B., \& Johnson, K. (2009). Theorizing language teacher identity: Three perspectives and beyond. Journal of Language, Identity and Education, 4(1), 21-44. https://doi.org/10.1207/s15327701jlie0401_2

Walkington, J. (2005). Becoming a teacher: Encouraging development of teacher identity through reflective practice. Asia-Pacific Journal of Teacher Education. 33(1), 53-64. https://doi.org/10.1080/1359866052000341124 


\section{APPENDIX}

Practicum Schools

\section{School}

. Public technical high- Morning and afternoon shifts school

Groups of 20 - 30 students

Level of English of students: Intermediate-Upper intermediate.

Age of the students: 15 - 17 years old

2. Public high-school

Afternoon shift

Groups of 35 - 45 students

Level of English of students: Beginner - Elementary

Age of the students: $15-17$ years old

3. Secondary school

Morning shift

Groups of $35-50$ students

C1- 1

Level of English of students:

Age of the students: 12 - 14 years old

4. Private elementary school

Morning shift

Pre-service teachers and cohort

Groups of 15- 20 students

$\mathrm{C} 1=2$

$\mathrm{C} 3=1$

Level of English of students: Beginner - elementary

Age of the students: 7 - 11 years old

5. Private catholic

Morning shift

Groups of 20- 30 students

C2- 1

C3- 1

Level of English of students: Beginner - elementary Age of the students: 9 - 11 years old
C1- 1

C2- 2

C3- 1

C2- 1

C3- 1 